\title{
The absolute recommendation of chamber Neubauer method for platelets counting instead of indirect methods in severe thrombocytopenic patients
}

\section{A absoluta recomendação de se usar o método direto de contagem de plaquetas em câmara de Neubauer em pacientes intensamente plaquetopênicos}

\author{
Raimundo Antônio Gomes Oliveira ${ }^{1}$ \\ Maria Mariko Takadachi ${ }^{2}$ \\ Kimiyo Nonoyama ${ }^{3}$ \\ Orlando Cesar de Oliveira Barretto ${ }^{4}$
}

\begin{tabular}{|c|c|}
\hline $\begin{array}{l}\text { platelet counts } \\
\text { thrombocytopenia } \\
\text { quality control } \\
\text { platelet transfusion }\end{array}$ & $\begin{array}{l}\text { Accurate and precise platelet counting is crucial for recommending platelets transfusion for } \\
\text { thrombocytopenic patients, principally when platelet counts are bellow } 30,000 / \mu l \text {. As most laboratories } \\
\text { still use the indirect methods for confirming low automated platelet counts, this work compared two } \\
\text { indirect methods used in practice (Fonio and Nosanchunk et al.) with the International Committee for } \\
\text { Standardization in Hematology recommended direct method (Brecher and Cronkite). The obtained data } \\
\text { show that the indirect methods present low precision and accuracy, and that the direct method should } \\
\text { always be employed in severe thrombocytopenic samples thanks to its high precision. }\end{array}$ \\
\hline
\end{tabular}

\section{resumo}

A contagem precisa e exata de plaquetas é crucial para se indicar ou não a transfusão de plaquetas em pacientes plaquetopênicos, principalmente quando as contagens estão abaixo de $30.000 / \mu$ l. Como muitos laboratórios ainda utilizam as contagens indiretas em esfregaço para confirmar baixas contagens obtidas por automação, este trabalho se propôs a comparar dois métodos indiretos muito usados (Fonio e Nosanchunk et al.) com o método direto indicado pelo Comitê Internacional de Estandardização em Hematologia (ICSH) (Brecher e Cronkite). Os dados obtidos demonstram que os métodos indiretos em esfregaço apresentam baixa precisão e exatidão e que o método direto de referência deve ser usado para confirmar as contagens em amostras intensamente plaquetopênicas.

\section{Introduction}

Platelet counting is an important tool used in clinical investigation to avoid bleeding risks. There is a general agreement that automation brought precision and accuracy for platelet counts in healthy individuals. Nevertheless, reliable platelet counts in thrombocytopenic patients is still controversial $(6,11$, 15, 19).

Based on the studies of Gaydos et al. (1962), most of the institutions use $20.000 / \mu \mathrm{l}$ (7) as threshold for platelet transfusion, whereas others employ $10.000 / \mu$ l $(3,9,10,14,16,17)$.
The Brecher and Cronkite $(4,5)$ direct manual method has been recommended by the International Committee for Standardization in Hematology ICSH (1984/1988).

Unfortunately the majority of hematology laboratories still employ indirect manual methods (blood smears) for confirming low platelet counting obtained in automated counters. The objective of this work was to evaluate the most used indirect methods and compare them with the manual direct standard method.
1. M.S.; assistant professor of Hematologia Clínica of Universidade Federal do Maranhão (UFMA); biochemistpharmacist of the Hospita Universitário Presidente Dutra of UFMA, São Luís, MA, Brazil. 2. Biochemist-pharmacist, Laboratório de Hematologia of the Hospital dos Servidores Públicos do Estado de São Paulo, São Paulo, SP, Brazil.

3. M.S., Seção de Hematologia of Divisão de Patologia of Instituto Adolfo Lutz, São Paulo, SP, Brazil. 4. M.D.; associate professor, Faculdade de Medicina of Universidade de São Paulo, LIM-23, São Paulo, SP, Brazil. This work is part of Raimundo Antônio Comes Oliveira's mastership thesis presented to the Faculdade de Ciências Farmacêuticas of USP in June, 2000. 


\section{Methods}

Peripheral blood samples of 43 thrombocytopenic patients with platelet counts lower than $30,000 \mathrm{plt} / \mu \mathrm{l}$ were analyzed. They were collected at the Hematology Service of the Hospital do Servidor Público Estadual (São Paulo-SP)

Blood smear indirect method 1: Nosanchung et al. (18) and Apibal et al. (1). Blood smear indirect method 2: Fonio (8).

ICSH $(1984 / 1988)(12,13)$ direct reference method: the Brecher and Cronkite method $(4,5)$, which requires Neubauer improved counting chamber.

The indirect platelet counting methods were performed in triplicate. Each count was obtained as the mean of 10 oil immersion fields (1000x amplification), in a total of 30 fields.

The ICSH method was also analyzed by triplicate counts. For every counting a sample was diluted in triplicate. The minimum of 200 platelets at Neubauer chamber was taken as standard procedure. The mean, standard deviation, and coefficient of variation for the manual (direct and indirect) platelet counts were compared with the direct method. Analysis of variance statistical test was employed.

\section{Results}

The results are shown in Tables $\mathbf{1}$ and $\mathbf{2}$. They indicate that indirect manual methods with variation coefficients higher than the upper acceptable threshold (15\%) have lower precision and accuracy when compared to the direct reference method (Tables 1 and 2).

Analysis of variance, with Tukey
test, between the indirect methods
Table 1
and reference method (ICSH)

ICSH: Brecher-Cronkite reference method; ind. met. 1: indirect method 1; ind. met. 2: indirect method 2.

The variable is the coefficient of variation $(\mathrm{CV})$ in patients with less than $30,000 \mathrm{plt} / \mu \mathrm{l}(\mathrm{n}=43)$.
Precision analysis on

thrombocytopenic subgroups according to thresholds established

Table 2 by literature for platelet transfusion

\begin{tabular}{|c|c|c|c|}
\hline Method & $\leq 10,000 \mathrm{plt} / \mu$ & $\begin{array}{c}10,000 \text { to } \\
20,000 \mathrm{plt} / \mu \mathrm{l} \\
\mathrm{CV}(\%)\end{array}$ & $>20,000 \mathrm{plt} / \mu \mathrm{l}$ \\
\hline ICSH & 11.8 & 12 & 8.2 \\
\hline Ind. met. & 138.6 & 24.7 & 19.5 \\
\hline Ind. met. & 236.7 & 24 & 18.7 \\
\hline
\end{tabular}

CV: coefficient of variation; ICSH: Brecher-Cronkite reference method; $\mathrm{p}<0.001$; ind. met. 1: indirect method 1; ind. met. 2: indirect method 2.

\section{Discussion}

According to Berkson (2), the specific error of hemocytometer depends on the number of cells which are counted in each area of the reticulum. Using the formula proposed by this author in similar conditions to this study, the chamber error itself would be of CV = $7.59 \%$. Therefore, as 200 cells were always counted, these experiments disclosed CV $=10.49 \%$ for platelet counts less than $30,000 / \mu \mathrm{l}$, and are similar to the data obtained by Dickerhof et al. (6) for platelets around $10,000 / \mu \mathrm{l}(\mathrm{CV}=14.7 \%)$. Hanseler et al. (11) results show that the correct use of the Neubauer chamber presents a satisfactory precision $(\mathrm{CV}<15 \%)$ in counts above $4,000 \mathrm{plt} / \mu \mathrm{l}$.

The results listed in Tables 1 and 2 indicate that the direct hemocytometer method is much more precise than the indirect methods in thrombocytopenic patients. For levels lower than $40,000 \mathrm{plt} / \mu \mathrm{l}$, the results obtained by Lawrence (16) (CV = 30.4\%, $p<0.001)$ confirm the lower precision of indirect methods.

Based on the threshold established for prophylactic platelet transfusion $(10,000$ or $20,000 \mathrm{plt} / \mu \mathrm{l})$, the results obtained by the indirect methods show that even triplicate counts, of 10 fields each, may jeopardize the clinical decisions when prophylactic or even therapeutic platelet transfusion are in discussion.

\section{Conclusion}

The direct Neubauer chamber method for levels lower than $30,000 \mathrm{plt} / \mu \mathrm{l}$ seems to be the most accurate and precise method for patients presenting bleeding risks. 
When precision is required for taking decisions regarding platelet transfusion indication, the blood smear methods are not helpful and may even impair them.

\section{References}

1. Apibal, S. et al. The effects of hemotocrit on visual platelet estimation. Am. J. Med.Technol., 45: 785-86, 1979.

2. Berkson, J. et al.The error of estimate of blood cell counts as made with the hemocytometer. Am.J.Physiol., 128:309-23, 1940.

3. Beutler, E. Platelet transfusions: the 20,000/ul trigger. Blood,337: 1914-15, 1997.

4. Brecher, G. \& Cronkite, E.P. Morphology and enumeration of human blood platelets. J.Appl. Physiol., 3: 365-77, 1950.

5. Brecher, G. et al. The reproducibility and consistency of the platelet count. Am.J. Clin. Pathol., 23: 15-26, 1953.

6. Dickerhoff, R. et al. Enumeration of platelets by multiparameter flow cytometry using platelet-specific antibodies and fluo rescent reference particles. Clin. Lab. H aematol., 17: 16372, 1995.

7. Finazzi, G. Prophylactic platelet transfusion in acute leukemia: which threshold should be used? Haematologica, 83: 96162, 1998.

8. Fonio, A. U eber ein neues Verfahren der Blutplattchenzahlung. Deustche Z eitschrieft Fur Chirurgie, 117: 176, 1912.

9. Gil-Fernandez, J.j. et al. C linical results of a stringent policy on prophylactic platelet transfusion: non-randomized comparative analysis in 190 bone marrow transplant patients from a single institution. Bone Marrow Transp., 18: 931-35, 1996.

10. G mür,J.et al.Safety of stringent prophylactic platelet transfusion policy for patients with acute leukemia. Lancet, 338: 122326, 1991.
11. Hanseler, E. et al. Estimation of the lower limits of manual and automated platelet counting. Am.J. Clin. Pathol.,105(6): 78287, 1996.

12. ICSH - International Committee for Standardization in Haematology.Selected method for visual platelet counting. Labmedica, 5: 31-4, 1988.

13. International Committee for Standardization in $\mathrm{H}$ aematology. Pro tocol for evaluation of automated blood cell co unters. Clin. Lab. Haematol., 6: 69-84, 1984.

14. Kruskall, M.S. The perils of platelet transfusions. N ew Engl. J. Med., 337: 1914-15, 1997.

15. Kunicka,. .et al.A ccurate quantitation of platelets on the $A \mathrm{dvia}^{\top \mathrm{M}}$ 120 hematology system. In:Bayer. Advia ${ }^{\text {TM }} 120 \mathrm{H}$ ematology System.

16. Lawrence, J.B. et al. Reliability of automated platelet counts: comparison with manual method and utility for prediction of clinical bleeding. Am. J. Hematol., 48: 24450, 1995.

17. N avarro, J.T. et al. Prophylactic platelet transfusion threshold during therapy for adult acute myeloid leukemia: $10,000 / \mu \mathrm{l}$ versus $20,000 / \mu \mathrm{l}$. Haematologica, 83: 998-1000, 1998.

18. N osanchuk, J.S. et al.The analytic basis for the use of platelet estimates from peripheral blood smears. Am. J.Clin. Pathol, 69:383-85, 1978.

19. Stanworth, S.J. et al. Automated counting of platelets on the Bayer A dvia ${ }^{\top M} 120$ analyser. Clin. Lab. Haematol., 21:113-7, 1999. 